\title{
Implementasi Norma Internasional mengenai Kebebasan Beragama dan Berkeyakinan di Indonesia
}

\author{
Muhammad Iqbal Yunazwardi \\ Universitas Indonesia
}

Aulia Nabila

Universitas Brawijaya

\begin{abstract}
Abstrak
Indonesia telah meratifikasi International Covenant of Civil and Political Rights (ICCPR) serta telah menjamin Kebebasan Beragama dan Berkeyakinan (KBB). Namun, pelanggaran KBB masih terjadi pasca tahun 2015. Artikel ini menganalisis permasalahan tersebut menggunakan konsep lokalisasi norma yang berasumsi bahwa implementasi norma internasional merupakan faktor utama yang mempengaruhi upaya Indonesia untuk mengimplementasikan KBB. Terdapat gap antara norma internasional, yakni Pasal 18 ICCPR dan hukum positif Indonesia yang mengatur tentang KBB. Selain itu, karakteristik demografi agama dan perilaku beragama masyarakat Indonesia berpengaruh terhadap implementasi KBB. Alhasil, upaya implementasi norma yang dilakukan oleh aktor lokal seperti Komnas HAM kurang maksimal. Artikel ini menyimpulkan bahwa dalam implementasi norma, pemerintah menafsirkan konteks sosial dan politik masyarakat. Acap kali, pemerintah terdesak oleh desakan beberapa oknum masyarakat sehingga negara berpotensi menjadi pelanggar atas aturan-aturan KBB yang telah disepakati sebelumnya.
\end{abstract}

Kata-kata kunci: ICCPR; kebebasan beragama dan berkeyakinan; lokalisasi norma

\begin{abstract}
Indonesia has ratified the International Covenant of Civil and Political Rights (ICCPR) and guarantees freedom of religion or belief (FoR). However, violations of FoR in Indonesia remains occur after 2015. This paper analyses this issue using the concept of norms localization which assumes that the implementation of international norms is the main factor that affects Indonesia's effort to implement the FoR. There is a gap between international norms, that is Article 18 of the ICCPR and the Indonesia's positive law regulating FoR. In addition, the characteristics of religious demography and religious behaviour of Indonesian people affect the implementation of FoR. As a result, the implementation of the norms by local actors such as the National Commission of Human Rights (Komnas HAM) is diminished. This paper concludes that in implementing the norms the government interprets the social and political context at societal level. The government is oftently forced by certain groups so it could be the potential violator of the FoR regulations that has been agreed upon.
\end{abstract}

Keywords: ICCPR; freedom of religion or belief; norms localization 


\section{Latar Belakang}

Terlepas dari jaminan negara untuk beribadat sesuai agama dan kepercayaan masing-masing secara merdeka sesuai Pasal 29 ayat (2) UUD 1945, Indonesia masih menghadapi berbagai isu terkait kebebasan beragama dan berkeyakinan (KBB). Data-data yang dihimpun oleh Komnas HAM dan lembaga swadaya masyarakat mengindikasikan bahwa pelanggaran KBB masih terjadi pasca tahun 2015 dengan jumlah yang tidak bisa dibilang sedikit. Misalnya, Komnas HAM melaporkan bahwa sepanjang tahun 2016 terdapat 97 pengaduan terkait dugaan pelanggaran KBB di mana paling banyak berupa pembatasan, pelarangan, dan perusakan tempat ibadah; pembatasan atau pelarangan ibadah dan kegiatan keagamaan; dan ancaman atau intimidasi kelompok keagamaan (Komnas HAM, 2019). Sementara itu, Wahid Foundation (2018) mencatat terdapat 213 peristiwa yang mengindikasikan pelanggaran KBB sepanjang tahun 2017 yang meliputi kriminalisasi berdasarkan agama; diskriminasi, pembatasan, pelarangan, dan penutupan tempat ibadah, dan intimidasi. Setara Institute (2018) mencatat di tengah tahun pertama 2018 terdapat 109 peristiwa pelanggaran KBB yang meliputi kriminalisasi, diskriminasi, dan intoleransi. Data-data ini menunjukkan bahwa jaminan KBB yang tertulis dalam UUD 1945 tersebut masih belum cukup mengatasi berbagai masalah terkait.

KBB sendiri telah menjadi bagian dari jaminan hak asasi manusia (HAM) dalam hukum internasional. Jaminan KBB dalam hukum internasional yang telah diterima hampir semua negara di dunia adalah Pasal 18 International Covenant on Civil and Political Rights (ICCPR) (United Nations Treaty Collection). ICCPR merupakan bagian dari The International Bill of Human Rights yang terdiri atas Universal Declaration of Human Rights, International Covenant on Economic, Social, and Cultural Rights (ICESCR) dan ICCPR sendiri sebagai instrumen internasional HAM pokok (Smith, ed., 2008). Ketiga instrumen ini ditetapkan di forum Perserikatan Bangsabangsa (PBB) pasca Perang Dunia Kedua (PD II) sebagai bentuk komitmen organisasi ini untuk "memajukan dan mendukung penghormatan terhadap hak asasi manusia dan kebebasan-kebebasan fundamental" (Moeckli et al., 2014).

Indonesia telah meratifikasi ICCPR dengan Undang-undang (UU) Nomor 12 Tahun 2005. Hal ini memberikan konsekuensi yakni berupa kewajiban yang dimiliki Indonesia untuk menjamin KBB sesuai standar internasional menurut ICCPR. Kewajiban ini harus terwujud baik dalam tata peraturan perundang-undangan maupun dari kelembagaan (UNHCR, 2014). Ini berarti bahwa dengan diratifikasinya ICCPR, Indonesia harus melakukan penyesuaian-penyesuaian tertentu dalam sistem hukumnya terhadap standar internasional jaminan HAM berdasarkan ICCPR, tak terkecuali KBB.

Indonesia sebenarnya telah memiliki norma KBB sendiri sebelum meratifikasi ICCPR. Ini dapat ditemukan dalam konstitusi Indonesia sebagaimana telah disebutkan di atas, yakni Pasal 29 ayat (2) UUD 1945. Pasal ini terdapat dalam naskah asli UUD 1945 yang ditetapkan pada tanggal 
18 Agustus 1945. Bersama Pasal 29 ayat (1), pasal ini bunyinya tetap sama hingga amandemen keempat sehingga merupakan salah satu dari pasalpasal yang 'selamat' dari perubahan. Dalam UUD 1945 pasca amandemen sendiri telah dicantumkan Bab XA yang menguraikan sejumlah hak asasi manusia. Dalam bab tersebut jaminan KBB terdapat dalam Pasal 28E ayat (1) dan (2) yang berbunyi: (1) Setiap orang berhak memeluk agama dan beribadat menurut agamanya, memilih pendidikan dan pengajaran, memilih pekerjaan, memilih kewarganegaraan, memilih tempat tinggal di wilayah negara dan meninggalkannya, serta berhak kembali.; (2) Setiap orang berhak atas kebebasan meyakini kepercayaan, menyatakan pikiran dan sikap, sesuai dengan hati nuraninya.

Oleh karena itu, perlu dikaji bagaimana proses masuknya normanorma hukum KBB berdasarkan ICCPR, yang merupakan hukum internasional, di Indonesia. Perlu juga dikaji apakah norma-norma ICCPR tersebut sudah 'meresap' ke dalam sistem hukum Indonesia secara keseluruhan. Penelitian ini akan menjelaskan bagaimana proses masuknya norma KBB ICCPR ke dalam tata hukum dan masyarakat Indonesia. Hal ini diharapkan dapat menjelaskan kebijakan implementasi KBB yang lebih menekankan pada aspek formal (ratifikasi) semata dibandingkan perlindungan dan penjaminan hak atas KBB secara substantif.

Beberapa penelitian terdahulu telah mencoba membangun kontribusi terhadap masalah masalah dalam implementasi norma HAM internasional. Seringkali, implementasi norma HAM bermasalah saat akan diterapkan di negara berkembang. Monshiouri (2001) menjelaskan bahwa nilai-nilai universalisme barat seringkali mendesak negara dunia ketiga untuk menjadi modern tanpa melihat konteks kelokalan yang kompleks. Dalam konteks negara berkembang, HAM sering kali dilihat sebagai bentuk perjuangan sosial dibandingkan landasan moral yang abstrak. Beberapa penelitian lain secara tidak langsung mendukung argumen ini dengan menjelaskan berbagai masalah yang terjadi di negara-negara dunia ketiga. Seperti contoh di dalam negara-negara yang menggunakan dasar bernegara melalui agama, norma HAM internasional sering kali bertabrakan dengan konteks kelokalan. Kelompok relativis menganggap bahwa sulit atau bahkan tidak mungkin untuk menerjemahkan HAM universal ke dalam budaya yang menekan peran keluarga dan kehidupan masyarakat, khususnya dalam budaya di mana agama memegang peranan penting (Hamid \& Sani, 2011; Setiawan, 2016).

Masalah ini menandai perdebatan penting antara gagasan universalisme dan partikularisme dalam HAM, khususnya dalam KBB. Selama ini, implementasi norma KBB sering kali gagal saat berusaha untuk mendapatkan legitimasi kultural. Alasannya, terdapat perdebatan terhadap benturan sekularisme nilai universal dengan relativitas kultur yang sarat akan nilai agama maupun ketauhidan. Selain itu, sifat bahasa 'hak' seringkali diperebutkan, termasuk ketegangan antara hak individu dan hak kolektif (Grull \& Wilson, 2018). Akan tetapi apabila berkaca dari pemikiran universal, masalah dari norma HAM universal tidak terletak 
pada esensi norma itu sendiri, akan tetapi, penolakan tersebut terjadi karena mental superioritas negara barat dalam membawa norma HAM internasional yang menimbulkan kecurigaan hingga penolakan (Donelly, 2013).

Perdebatan di atas pada akhirnya akan mempengaruhi sosialisasi hingga tingkat kesuksesan implementasi norma di negara-negara. Sekalipun sebuah norma internasional bisa disepakati dan diratifikasi, implementasi di tingkat lokal, sering kali tidak sesuai maupun gagal diterapkan (Huells, 2017). Menurut Cortell dan Davis (2005), internalisasi norma internasional acap kali tidak menguntungkan karena tidak ada pemahaman di tingkat nasional. Sedangkan menurut Acharya (2004), masalah internalisasi terkait dengan dikotomi kebenaran yang menafsirkan norma global sebagai hal baik yang berpotensi mengalahkan keyakinan praktik lokal. Oleh karena itu, Acharya merasa bahwa internalisasi norma internasional terlalu 'keras' dan tidak mampu menyesuaikan konteks kelokalan. Dalam konteks norma KBB internasional, visi negara untuk mengimplementasikan norma akan berbenturan dengan realita politik domestik maupun populisme kultural yang sangat terkait dengan permasalahan elektoral (Colbran, 2010). Pada akhirnya, implementasi norma internasional KBB yang berfungsi untuk melindungi hak kelompok minoritas akan selalu berbenturan dengan keinginan kelompok populis maupun konservatif yang berusaha untuk terus menjaga nilai relativitas dan mengutuk nilai-nilai KBB internasional sebagai bentuk sekularisasi (Hamoyotsu, 2013).

Artikel ini berasumsi bahwa implementasi norma internasional merupakan faktor utama yang mempengaruhi perilaku Indonesia dalam upayanya untuk mengimplementasikan hak atas KBB. Oleh karena itu, negara akan melakukan penyerapan norma dan menciptakan produk norma yang sesuai dengan kebutuhan Indonesia dengan cara meratifikasi aturan-aturan internasional. Akan tetapi, hipotesis dari penelitian ini adalah perilaku Indonesia saat ini belum mengedepankan aspek hak atas KBB, terutama bagi kelompok minoritas. Upaya untuk membangun argumentasi ini akan dilakukan dengan cara analisis studi kasus yang intensif, yaitu dengan menganalisis data-data perbandingan aturan internasional dengan hukum positif Indonesia, proses politik ratifikasi, dan implementasi norma KBB di tengah masyarakat Indonesia.

\section{Kerangka Konseptual: Implementasi Norma HAM Internasional}

Penjelasan mengenai difusi norma transnasional telah menjadi pembahasan utama dalam kajian konstruktivis. Menurut Finnemore dan Sikkink (1998), norma transnasional dapat berkembang dikarenakan promosi yang dilakukan suatu aktor yang diawali dengan mengembangkan norma domestik, kemudian menjadi norma internasional, dan diturunkan kembali ke tingkat domestik. Akan tetapi, Finnemore dan Sikkink tidak menawarkan pembenaran teoritis yang meyakinkan untuk menggeser tingkat analisis dari politik domestik negara bagian ke sistem internasional dalam memperhitungkan pengaruh norma pada tahap selanjutnya 
dalam siklus kehidupan. Selain itu, terdapat permasalahan utama dalam implementasi dan fungsi difusi norma. Seperti contoh, apakah normanorma internasional memiliki spesifikasi yang berbeda, ketika negara tersebut adalah negara demokrasi? Perbedaan ini menurut Risse dan Sikkink (1999) membuat difusi norma tidak bisa selamanya digeneralisasi proses internalisasinya.

Negara-negara dengan situasi domestik dan internasional yang kurang menguntungkan akan menjadi kasus sulit untuk memahami kondisi di mana norma-norma HAM internasional dapat menyebabkan perubahan praktik domestik. Akan tetapi, proses pengkajian norma selalu berfokus pada tahap internalisasi semata. Peneliti-peneliti norma sering kali berfokus pada beberapa topik major seperti 'socialization' (Risse \& Sikkink; 1999), 'norm diffusion' (Finnemore \& Sikkink, 1998), 'norm entrepreneurs' (Sunstein 1996; Finnemore \& Sikkink, 1998), logic of appropriateness (March \& Olseen, 1989) dan kontestasi prinsip norma (Wiener, 2007; Wiener 2014).

Ukuran norma sejatinya dapat dilihat dari proses sosialisasi dan implementasinya juga. Sepuluh tahun lebih setelah merilis bukunya yang berjudul The Power of Human Rights: International Norms and Domestic Change pada tahun 1999, Thomas Risse, Kathryn Sikkink dan Stephen Ropp melihat terdapat beberapa kelemahan dalam konsep Model Spiral yang mereka tawarkan. Dalam buku mereka yang berjudul The Persistent of Human Rights: From Commitment to Compliance, kelemahan tersebut terletak pada tidak adanya pondasi pemikiran yang kuat terhadap bentuk kepatuhan aktor-aktor atas norma-norma yang telah disepakati. Kepatuhan aktoraktor sejatinya berasal dari komitmen dan kemauan atas norma-norma HAM yang telah disepakati dan dilembagakan.

Sedangkan menurut Huelss (2017), penelitian yang ada hanya meneliti pertanyaan mengapa aktor mengikuti norma-norma tertentu dan bagaimana memahami berbagai tingkat kepatuhan. Dalam hal ini, penelitian cenderung mengabaikan bagaimana norma diterapkan, khususnya teknik yang digunakan untuk mengoperasionalkan norma dalam praktik. Huelss (2017) menekankan pentingnya analisis mekanisme dampak norma (HAM) atau konsepsi demokrasi, yang dikodifikasi dalam dokumen tertulis, direproduksi dalam wacana dan diharapkan untuk membentuk keputusan - hanya diberikan substansi dalam membuat mereka beroperasi secara administratif dan mengimplementasikannya di lapangan. Divergensi dan konvergensi makna yang dikaitkan dengan norma-norma tersebut telah menerima banyak perhatian. Namun, analisis konten normatif dalam HI sering berfokus pada arena pengambilan keputusan internasional secara luas, dan mengabaikan kemungkinan bahwa operasionalisasi norma dapat memiliki efek transformatif.

Akan tetapi, terdapat kritik terhadap penjelasan difusi norma yang diberikan oleh Finnemore dan Sikkink. Pertama, norma universal yang diadopsi sering kali tidak memperhatikan konteks kelokalan. Sehingga penerima ditingkat nasional merasa bahwa norma yang akan diadaptasi bersifat keras dan kaku. Kondisi ini sering terjadi saat sebuah negara merasa 
bahwa norma tersebut berpotensi untuk mengganggu nilai kelolakan yang ada di suatu negara. Kedua, gagasan Finnemore dan Sikkink tidak memperhatikan ketika norma internasional diturunkan kembali ke dalam norma domestik.

Penelitian ini menggunakan konsep lokalisasi norma yang dicetuskan oleh Amitav Acharya. Menurut Acharya (2009), lokalisasi norma adalah upaya untuk menggambarkan kompleksitas proses dan hasil dimana penyerap norma membangun kesesuaian antara norma norma transnasional dan kepercayaan praktik lokal. Oleh karena itu menurut Acharya (2004), sebuah norma haruslah melewati pertimbangan lokal agar mampu diterima. Peluang dalam proses lokalisasi norma adalah kunci untuk melihat seberapa besar sebuah norma. Dalam tulisannya, lokalisasi yang dimaksud Acharya lebih luas cakupannya daripada proses framing dan grafting di dalam teori difusi internasional. Lokalisasi digunakan untuk menyatukan kedua proses tersebut ke dalam satu kerangka kerja tunggal yang menekankan pada peran agensi atau aktor lokal dalam pelaksanaannya.

Selain itu dalam lokalisasi, agen lokal memegang peranan penting. Dimana, aktor lokal memproses norma yang akan diterapkan dan disesuaikan dengan kontek kelokalan. Dalam beberapa kasus, lokalisasi sering dikaitkan dengan proses adaptasi. Tetapi adaptasi adalah istilah umum yang dapat mencakup semua jenis perilaku dan hasil. Lokalisasi memiliki fitur yang lebih spesifik. Dalam lokalisasi, inisiatif untuk mencari perubahan biasanya milik aktor lokal. Apabila adaptasi dilakukan untuk mematuhi norma internasional, lokalisasi dilakukan secara khusus untuk memenuhi kepentingan-kepentingan lokal.

Hasil akhir dari lokalisasi adalah praktik-praktik terlihat seperti mematuhi norma internasional, namun mempertahankan norma-norma lokal yang telah ada sebelumnya. Menurut Acharya (2009), lokalisasi dapat terjadi karena tiga faktor. Faktor tersebut antara lain (1) norma domestik sudah diterapkan, tetapi terancam digantikan atau bertabrakan oleh norma internasional, (2) elit di tingkat domestik merasa bahwa norma internasional dapat dimodifikasi dalam upaya untuk memperkuat legitimasi tingkat domestik yang berdasarkan pada norma domestik yang sudah ada; dan (3) adanya kehadiran aktor domestik yang memiliki pengaruh diskursif lebih kuat dibandingkan norm entrepreneur internasional dari luar negara tersebut. Hasil dari lokalisasi kemungkinan akan menghasilkan dua perubahan institusional. Perubahan tersebut antara lain: (1) perubahan tugas (dan fungsi) serta perluasan keanggotaan dan (2) perubahan prosedural atau penciptaan instrumen kebijakan baru. Kegagalan implementasi norma maupun penerimaan norma akan tercipta apabila lokalisasi tidak dijalankan.

Oleh karena itu, penting untuk melihat bagaimana proses negara memulai ratifikasi setelah menyetujui masuknya norma internasional ke dalam diskursus politik nasional. Selain itu, penelitian ini akan melihat kondisi bahwa terdapat celah yang cukup besar dalam implementasi norma internasional dalam kodifikasi hukum positif negara. Celah tersebut 
berpotensi menimbulkan ketidakefektifan norma yang sudah diterapkan. Selain itu, penelitian akan menjelaskan tantangan mendasar pada proses implementasi norma, yaitu bagaimana kondisi di lapangan tidak terlihat sesuai. Bahkan, negara sebagai aktor penting yang meratifikasi norma KBB menjadi aktor utama yang melanggar implementasi norma tersebut. Artikel ini akan membahas secara menyeluruh perihal bagaimana terciptanya ruang yang cukup besar antara komitmen ratifikasi norma internasional dengan implementasi yang terjadi di dalam realita. Kegagalan dalam implementasi norma KBB internasional akan menyimpulkan bahwa bagaimana perspektif domestik memahami konteks norma KBB internasional

\section{Ratifikasi ICCPR oleh Indonesia}

Indonesia berada pada masa pemerintahan rezim otoritarian selama empat dekade, yakni di periode Demokrasi Terpimpin atau Orde Lama (19591966) dan selama periode Orde Baru (1966-1998). Di dua periode tersebut, stabilitas nasional menjadi perhatian utama pemerintah, walau sebenarnya telah ada diskusi-diskusi yang berupaya untuk menetapkan sebuah instrumen HAM. Di masa Orde Baru, misalnya, Majelis Permusyawaratan RakyatSementara(MPRS) yang dibentuk olehKeppres Nomor 150 Tahun 159 (Dekrit Presiden 1959) itu telah berhasil menetapkan sebuah "Piagam HakHak Asasi Manusia dan Hak-Hak Serta Kewajiban Warga Negara." Namun, karena corak politik di periode itu dihiasi oleh usaha mempertahankan stabilitas politik dan kekuasaan rezim, pemerintahan malah bersikap anti terhadap eksistensi suatu piagam hak asasi manusia (Smith et al., 2008: 250). Keberadaan piagam hak asasi manusia dianggap tidak perlu dengan alasan masalah HAM sudah diatur dalam peraturan perundang-undangan (Smith et al., 2008: 250). Tidak adanya kerangka berpikir HAM di periode inilah yang mendukung banyak terjadinya berbagai pelanggaran HAM di era ini.

Pada tahun 1998, yakni pasca jatuhnya rezim Orde Baru dan lahirnya era Reformasi, ditetapkan Rencana Aksi Nasional Hak Asasi Manusia (RANHAM) dengan Keppres Nomor 129 Tahun 1998. RANHAM merupakan dokumen perencanaan strategis berjangka waktu lima tahun. Agenda RANHAM pertama itu yakni (Wardaya, 2009: 7): (1) persiapan pengesahan perangkat internasional HAM; (2) diseminasi dan pendidikan HAM; (3) pelaksanaan HAM yang ditetapkan sebagai prioritas; (4) pelaksanaan isi atau ketentuan berbagai perangkat internasional HAM yang telah disahkan Indonesia; (5) Penerapan norma dan standar Hak Asasi Manusia; dan (6) pemantauan, evaluasi dan pelaporan. RANHAM yang pertama ini berakhir masa berlakunya di tahun 2003. Kemudian RANHAM dilanjutkan di periode 2004-2009, yang ditetapkan melalui Keppres No. 40 Tahun 2004. ICCPR yang diratifikasi oleh UU Nomor 12 Tahun 2005 merupakan bagian dari agenda RANHAM periode kedua ini.

Dengan demikian, ratifikasi ICCPR merupakan bagian dari agenda Reformasi. Awal masa Reformasi ini memang dihiasi dengan agendaagenda yang menampakkan 'euforia', di antaranya adalah amandemen UUD 1945 di mana disertakan Bab XA yang mengatur HAM secara khusus dan pembentukan berbagai peraturan perundang-undangan yang 
berkaitan dengan HAM, misalnya UU No. 39 Tahun 1999 Tentang HAM, UU Nomor 9 Tahun 1998 Tentang Kebebasan Menyampaikan Pendapat, dan UU Nomor 9 Tahun 1999 Tentang Pers. Hal ini dapat dipahami sebagai upaya 'penebusan' atas berbagai pelanggaran HAM yang terjadi di era Orde Baru.

Akan tetapi, proses pembentukan peraturan perundang-undangan dan ratifikasi itu melalui proses yang singkat. Ratifikasi ICCPR dan ICESCR dilakukan hanya enam tahun setelahjatuhnya rezim otoritarian di Indonesia. Kenyataannya, meski berbagai instrumen hukum yang mendukung HAM sudah tersedia dan berlaku, masih ada berbagai pelanggaran HAM dan kesenjangan antara ketersediaan hukum dan kenyataan yang ada. Menurut Juwana (2006: 30), salah satu penyebab hal ini adalah proses pembentukan dan ratifikasi yang terkesan buru-buru dan hanya sekedar memenuhi tekanan organisasi internasional serta lembaga swadaya masyarakat (LSM), padahal kondisi di Indonesia belum siap untuk menerima berbagai norma HAM internasional yang masuk. Sikap Indonesia terhadap rezim internasional juga masih menunjukkan resistensi, atau dengan kata lain, Indonesia menghormati aturan-aturan HAM di level internasional, tetapi masih belum berkomitmen sepenuhnya menaati atau menerapkan aturan tersebut di wilayah negaranya, terutama dari segi prosedural (Citrawan, 2014: 246$){ }^{1}$

Hal ini dapat menjelaskan keberadaan kesenjangan antara norma internasional yang sudah diratifikasi dan keberlakuannya secara riil di Indonesia, juga tidak jelasnya konsep tanggung jawab negara dan kerangka 'implementatif' dalam pengaturan HAM di Indonesia (Wiratrawan, 2007: 8-16). Oleh karena berbagai perjanjian internasional di bidang HAM itu diratifikasi di momen-momen hangat awal Reformasi, hal ini menimbulkan kesan bahwa diratifikasinya perjanjian internasional itu, termasuk ICCPR, hanya dilakukan untuk meredam tekanan yang diterima pemerintah. Padahal, kondisi Indonesia, termasuk pemahaman para penegak hukum mengenai norma ICCPR itu sendiri, belum siap untuk melaksanakan ICCPR secara konkret.

\section{Kesenjangan antara jaminan KBB dalam ICCPR dan Hukum Positif Indonesia}

Subbab sebelumnya telah menjelaskan adanya kesenjangan antara

1 Hal ini dapat dilihat dari, misalnya, belum diratifikasinya optional protocols dari ICCPR dan ICESCR, yang berimbas pada diberikannya wewenang kepada lembaga PBB terkait (Human Rights Committee sebagai pemantau pelaksanaa ICCPR dan CESCR sebagai pemantau pelaksanaan ICESCR) untuk menerima komplain individu atas dugaan pelanggaran HAM oleh negara yang bersangkutan. Harison Citrawan, Menuju ASEAN Political and Security Community: Kritik dan Tantangan Politik Hukum Indonesia dalam Regionalisme ASEAN, Jurnal Rechtsvinding, Volume 3, Nomor 2, Agustus 2014, hlm. 246. 
ratifikasi ICCPR oleh Indonesia dan keberlakuannya secara konkret. Hal ini pun kemudian juga memberikan konsekuensi pada jaminan KBB di Indonesia, yang memiliki perbedaan-perbedaan dengan norma internasional KBB yang diatur dalam ICCPR. Sebelum membahas lebih jauh tentang kesenjangan antara dua norma tersebut, penting untuk melihat dan membandingkan ketentuan yang mengatur secara langsung tentang KBB dalam norma hukum internasional dan norma hukum nasional Indonesia, sebagai berikut.

Tabel 1

Norma KBB dalam Hukum HAM Internasional dan Hukum Positif Indonesia

\begin{tabular}{|c|c|}
\hline $8 \mathrm{ICCPR}$ & Hukum Positif Indonesia \\
\hline $\begin{array}{l}\text { 1. Setiap orang berhak atas kebebasan } \\
\text { berpikir, keyakinan dan beragama. } \\
\text { Hak ini mencakup kebebasan } \\
\text { untuk menetapkan agama atau } \\
\text { kepercayaan atas pilihannya sendiri, } \\
\text { dan kebebasan, baik secara sendiri } \\
\text { maupun bersama-sama dengan } \\
\text { orang lain, baik di tempat umum atau } \\
\text { tertutup, untuk menjalankan agama } \\
\text { dan kepercayaannya dalam kegiatan } \\
\text { ibadah, pentaatan, pengamalan, dan } \\
\text { pengajaran. }\end{array}$ & $\begin{array}{l}\text { Pasal 28E UUD 1945: } \\
\text { (1) Setiap orang berhak memeluk } \\
\text { agama dan beribadat menurut } \\
\text { agamanya, memilih pendidikan } \\
\text { dan pengajaran, memilih pekerjaan, } \\
\text { memilih kewarganegaraan, memilih } \\
\text { tempat tinggal di wilayah negara } \\
\text { dan meninggalkannya, serta berhak } \\
\text { kembali. } \\
\text { (2)Setiap orang berhak atas kebebasan } \\
\text { meyakini kepercayaan, menyatakan } \\
\text { pikiran dan sikap, sesuai dengan hati } \\
\text { nuraninya. }\end{array}$ \\
\hline $\begin{array}{l}\text { 2. Tidak seorang pun dapat dipaksa } \\
\text { sehingga terganggu kebebasannya } \\
\text { untuk menganut atau menetapkan } \\
\text { agama atau kepercayaannya sesuai } \\
\text { dengan pilihannya. }\end{array}$ & $\begin{array}{l}\text { Pasal } 29 \text { ayat (2) UUD 1945: Negara } \\
\text { menjamin kemerdekaan tiap- } \\
\text { tiap penduduk untuk memeluk } \\
\text { agamanya masing-masing dan untuk } \\
\text { beribadat menurut agamanya dan } \\
\text { kepercayaannya itu. }\end{array}$ \\
\hline $\begin{array}{l}\text { 4. Negara Pihak dalam Kovenan ini } \\
\text { berjanji untuk menghormatikebebasan } \\
\text { orang tua dan apabila diakui, wali } \\
\text { hukum yang sah, untuk memastikan } \\
\text { bahwa pendidikan agama dan moral } \\
\text { bagi anak-anak mereka sesuai dengan } \\
\text { keyakinan mereka sendiri. }\end{array}$ & $\begin{array}{l}\text { Pasal } 22 \text { UU No. } 39 \text { Tahun } 1999 \\
\text { Tentang Hak Asasi Manusia: } \\
\text { (1) Setiap orang bebas memeluk } \\
\text { agamanya masing-masing dan untuk } \\
\text { beribadat menurut agamanya dan } \\
\text { kepercayaannya itu. } \\
\text { (2) Negara menjamin kemerdekaan } \\
\text { setiap orang memeluk agamanya dan } \\
\text { kepercayaannya itu. }\end{array}$ \\
\hline
\end{tabular}


Pada tabel di atas dapat dilihat norma-norma internasional dan nasional KBB yang sama-sama berlaku di Indonesia. Di level internasional, KBB dijamin melalui Pasal 18 ICCPR. Pasal ini berlaku di Indonesia melalui ratifikasi dengan UU Nomor 12 Tahun 2005. Di level nasional, KBB dijamin dalam peraturan perundang-undangan yakni UUD 1945 dan UU Nomor 39 Tahun 1999 Tentang Hak Asasi Manusia. Pasal-pasal yang menjamin KBB tersebut yakni Pasal 28E ayat (1), 28E ayat (2), dan 29 ayat (2) UUD 1945 dan Pasal 22 UU Nomor 39 Tahun 1999. Pasal 29 ayat (2) adalah pasal yang ada dalam naskah asli UUD 1945 yang ditetapkan tanggal 18 Agustus 1945, atau dengan kata lain bukan merupakan hasil amandemen yang dilakukan di jangka waktu 1999-2002 (Asshidiqie, 2009: 353-354). ${ }^{2}$ Ini juga berarti bahwa pasal ini lahir sebelum diakuinya DUHAM dan diratifikasinya ICCPR oleh Indonesia. Selain itu, norma dalam Pasal 22 UU Nomor 39 Tahun 1999 pun muncul sebelum amandemen UUD 1945 yang berarti juga sebelum diratifikasinya ICCPR oleh Indonesia pada tahun 2005.

Namun UU Nomor 39 Tahun 1999 secara khusus telah menyatakan dalam konsiderannya bahwa UU tersebut dibuat salah satunya dalam menimbang posisi Indonesia sebagai negara anggota PBB yang menjunjung tinggi dan melaksanakan DUHAM. DUHAM sendiri bukanlah sebuah instrumen hukum, melainkan sebuah 'pernyataan sikap' dari negaranegara anggota PBB di tahun 1948 untuk menjamin HAM. Oleh karena itu, dapat dikatakan bahwa norma-norma KBB yang menjadi bagian dari hukum positif Indonesia telah ada sebelum masuknya ICCPR sebagai instrumen hukum internasional yang mewajibkan negara-negara untuk menjamin KBB. Hal ini dapat mengarah kepada dua kesimpulan: bahwa norma KBB dalam hukum positif Indonesia menjadikan DUHAM sebagai tolak ukurnya atau bahwa norma KBB dalam hukum positif Indonesia tidak dibuat dengan memperhatikan konsep-konsep KBB dalam ICCPR, mengingat waktu mulai diberlakukannya di Indonesia. Meski hal ini tidak berarti bahwa ada kesenjangan antara DUHAM dan ICCPR itu sendiri, atau DUHAM sebagai sebuah deklarasi atau pernyataan sikap negaranegara terhadap HAM tidak lebih lengkap dan konkret daripada ICCPR, yang merupakan perjanjian internasional yang mengikat negara-negara anggotanya, terkait pengaturan mengenai KBB. KBB dalam Pasal 18 ICCPR merupakan penjabaran yang lebih konkret dari Pasal 18 DUHAM, dengan melihat pula pasal 29 DUHAM sebagai klausula pembatasan.

\section{Ruang Lingkup Jaminan KBB dalam Norma Internasional dan Hukum Positif Indonesia}

ICCPR, sebagai norma internasional, memberikan jaminan yang luas bagi KBB. Perlindungan KBB dalam Pasal 18 tersebut tidak terbatas pada penganut agama apapun. Hal ini dapat dilihat dari Komentar Umum (General Comment) nomor 22 Human Rights Committee (HRC) 
yang menyatakan bahwa perlindungan KBB juga meliputi perlindungan terhadap (penganut) kepercayaan teistik, non-teistik, dan ateistik, bahkan juga melindungi hak untuk tidak menganut agama atau kepercayaan apapun (UNHRCR General Comment No.22, 2014). Sementara itu, di Indonesia, KBB dijamin bagi tiap-tiap pemeluk agama untuk menganut agama dan beribadat menurut agamanya itu, sebagaimana dikemukakan dalam Pasal 29 ayat (2). Selain itu, KBB juga dijamin dalam Pasal 28E ayat (1) dan (2), yang lebih luas lingkupnya dalam KBB karena juga meliputi kebebasan memiliki 'kepercayaan', meyakini kepercayaan, dan bertindak menurut kepercayaan itu.

Pasal 29 ayat (2) bersamaan dengan pasal 29 ayat (1) merupakan norma yang mengejawantahkan sila Ketuhanan Yang Maha Esa, yang merupakan bentuk kepercayaan masyarakat Indonesia terhadap Tuhan Yang Maha Esa. Hal ini kemudian memberikan corak yang cenderung teistik terhadap pemahaman mengenai agama di Indonesia, berbeda dengan Pasal 18 ICCPR yang memberikan perlindungan bagi semua penganut agama dan kepercayaan, bahkan bagi yang tidak menganut agama atau kepercayaan apapun. Sila Pertama Pancasila itu sendiri, menurut Safa'at, merupakan bentuk akomodasi antara pemahaman nasionalis dan Islamis dalam sidang pembahasan Piagam Jakarta (Safa'at, 2019: 10). Karena itu, dari perspektif historis perumusannya, sila ini tidak mengakomodasi agama-agama dan kepercayaan lokal (Safa'at, 2019: 39). Sila ini kemudian juga menjadi dasar dalam mengontrol secara ketat atau bahkan menolak eksistensi dari aliranaliran agama atau kepercayaan tertentu yang dilakukan melalui UU Nomor 1/PNPS/1965 tentang Pencegahan Penyalahgunaan dan Penodaan Agama (Safa'at, 2019: 39). UU ini pun secara praktik juga menjadi justifikasi dalam 'pengakuan' kepada enam agama, yakni Islam, Kristen, Katolik, Hindu, Buddha dan Konghucu, sehingga agama atau kepercayaan di luar enam itu tidak mendapatkan perlindungan dan pelayanan dari negara sebagaimana mestinya, atau dalam kasus-kasus tertentu didiskriminasi (Komnas HAM, 2019).

Selain itu, corak teistik dalam pemahaman agama di Indonesia juga tampak dalam UU lainnya yang berkaitan dengan administrasi kependudukan, seperti UU Nomor 23 Tahun 2006 tentang Administrasi Kependudukan dan UU Nomor 1 Tahun 1974 tentang Perkawinan. UU Administrasi Kependudukan, sebelum diuji secara materiil oleh Mahkamah Konstitusi (MK), mengandung ketentuan yang terkesan mendiskriminasi agama-agama dan kepercayaan lokal, karena memberikan perlakuan berbeda antara penganut enam agama tersebut di atas dan penganut agama-agama dan kepercayaan lokal, yang disebut sebagai "agama yang belum diakui sebagai agama." Kemudian, persoalan agama berpotensi mendiskriminasi penganut agama dan kepercayaan lokal juga muncul dalam Pasal 2 ayat (1) UU Perkawinan yang mengatur bahwa sahnya perkawinan adalah apabila dilakukan menurut hukum masing-masing agama dan kepercayaan, yang ditafsirkan sebagai enam agama 'utama' di Indonesia yang berada di bawah naungan Kementerian Agama (Safa'at, 2019). 
Hal-hal ini menimbulkan pemahaman bahwa dalam hukum Indonesia, agama dan kepercayaan yang tidak bersifat teistik tidak mendapatkan pengakuan, bahkan perlindungan dari jaminan KBB menurut hukum positif Indonesia yang mendapat pengaruh dari perspektif Sila Ketuhanan Yang Maha Esa. Bahkan, agama dan kepercayaan lokal Indonesia yang bersifat teistik, tetapi berada di luar enam agama 'utama' itu, masih mendapat risiko diskriminasi dalam praktik dikarenakan pemahaman mengenai agama di Indonesia secara sosiologis sudah terpaku pada enam agama tersebut.

\section{Penafsiran atas Norma-norma KBB Internasional dan Nasional}

Perbedaan pemahaman KBB antara norma internasional, yakni Pasal 18 ICCPR dan Hukum Positif Indonesia juga tampak dalam bagaimana lembaga-lembaga terkait menafsirkan norma-norma tersebut. Human Rights Committee (HRC), sebagai treaty body yang bertugas memantau pelaksanaan ICCPR oleh negara-negara anggota, memegang teguh prinsip universalitas dalam KBB dan jaminan KBB yang diberikan seluas-luasnya dan secara inklusif bagi penganut dan 'non-penganut' semua agama dan kepercayaan. Hal ini berimplikasi pada tingginya standar 'pengecualian' di mana negara dapat memberikan batasan terhadap KBB. Negara harus memberikan justifikasi yang cukup untuk membatasi KBB dan apabila tidak demikian, negara dapat dikatakan telah melanggar KBB (UNHCR, 2016). Penilaian terhadap justifikasi ini memperhatikan ketentuan Pasal 18 ayat (3) ICCPR yang mengatur bahwa KBB "hanya dapat dibatasi oleh ketentuan berdasarkan hukum, dan yang diperlukan untuk melindungi keamanan, ketertiban, kesehatan, atau moral masyarakat, atau hak-hak dan kebebasan mendasar orang lain."

Sementara itu, dalam putusan-putusannya, MK cenderung memperlihatkan corak teistik itu dalam memahami agama dan kepercayaan di Indonesia dan bahwa perlindungan KBB juga harus seimbang dengan perlindungan terhadap ketertiban umum. Hal ini misalnya tampak pada putusan MK mengenai uji materiil UU No. 1/PNPS/1965 yang menyatakan bahwa UU ini tetap harus dipertahankan karena jika tidak ada UU tersebut, dikhawatirkan akan ada "benturan serta konflik horizontal, serta dapat menimbulkan keresahan, perpecahan, dan permusuhan di masyarakat (Putusan Mahkamah Konstitusi No. 56/PUU-XV/, 2012: 530)."

MK juga menunjukkan perhatian terhadap perlindungan terhadap agama-agama yang sudah 'diakui' di Indonesia, misalnya dalam putusan mengenai uji materiil terhadap UU yang sama, yang kali ini permohonannya diajukan oleh penganut aliran Ahmadiyah di mana MK menyatakan bahwa penafsiran terhadap ajaran-ajaran agama "tidak boleh bertentangan dengan pokok-pokok ajaran agama itu sendiri, yang bersumber dari kitab suci (Putusan Mahkamah Konstitusi No 56/PUU-XV, 2017: 533)" MK di sini menekankan bahwa KBB yang dijamin di Indonesia tidak meliputi kebebasan sepenuhnya untuk menafsirkan ajaran agama-agama (Putusan Mahkamah Konstitusi No 56/PUU-XV, 2017: 531). Sikap MK terhadap 
norma internasional $\mathrm{KBB}$ cenderung ada pada sikap mengakui serta menghormati, namun tidak menjadikan norma internasional tersebut sebagai acuan utama dalam memberikan putusan terhadap suatu kasus. MK bahkan menggarisbawahi bahwa jaminan KBB dalam ICCPR dan dalam UUD 1945 memang berbeda karena dalam ICCPR nilai-nilai agama tidak termasuk dalam batasan HAM sebagaimana dalam Pasal 28J ayat (2) UUD 1945.

\section{Implementasi Norma Kebebasan Beragama di Indonesia: Visi Aktor Lokal dan Realita}

Implementasi norma HAM internasional dapat digunakan sebagai pisau analisis terhadap norma KBB transnasional dan dampak terhadap implementasi KBB di Indonesia. Indonesia telah meratifikasi ICCPR melalui UU RI Nomor 12 Tahun 2005 yang berarti menyepakati secara utuh pasal 18 ICCPR. Pasal tersebut menyatakan bahwa negara-negara diharapkan mampu untuk menjamin kebebasan beragama seperti menghargai pilihan masyarakat, tidak memaksakan kepercayaan, kebebasan untuk memanifestasikan agama, dan memastikan pendidikan agama dan moral masyarakat sesuai dengan keyakinan masing-masing. Namun pada implementasinya, Indonesia belum mampu dengan maksimal menciptakan norma transnasional KBB di Indonesia. Data dari Setara Institute (2018) mencatat dalam 12 tahun terakhir, total pelanggaran atas KBB mencapai 2.400 kasus. Setara juga mencatat bahwa Jawa Barat (629 kasus), DKI Jakarta (291 kasus) dan Jawa Timur (270 kasus) menjadi tiga provinsi dengan catatan pelanggaran atas KBB terbesar di Indonesia (Setara Institute, 2018)

Pelaku utama dalam tindak pelanggaran KBB tersebut berasal dari kelompok warga (600 kasus), ormas keagamaan (249 kasus), Majelis Ulama Indonesia (MUI) (242 tindakan), dan Front Pembela Islam (181 tindakan) (Setara Institute, 2018). Walau dalam pola penegakan HAM negara dianggap sebagai pelanggar potensial, tetapi dalam data tersebut terlihat bahwa negara tidak tercatat banyak. Beberapa kasus yang melibatkan negara sebagai aktor pelanggar KBB antara lain yaitu dalam kasus Gafatar (2016), SKB 3 menteri tentang pelarangan terhadap aktivitas dan kegiatan Ahmadiyah (2008), hingga penangkapan dan pelarangan aktivitas sekte pondok nabi Mangapin Sibue (2003). (Wahid Foundation, 2018; Setara Institute, 2018, Komnas HAM, 2019). Sering kali, upaya negara untuk melanggar kebebasan beragama dilakukan dengan menggunakan UU No.1/PNPS/1965. Pasal tersebut berisi larangan kepada masyarakat untuk melakukan penafsiran tentang sesuatu agama yang dianut di Indonesia maupun menyerupai kegiatan-kegiatan agama dan menyimpang dari pokok ajaran agama tersebut. Agama yang dimaksud dan diakui Indonesia adalah Islam, Kristen, Katolik, Hindu, Budha, dan Konghucu.

Tantangan utama dalam mengimplementasikan normal transnasional KBB di Indonesia adalah memahami karakteristik demografi agama dan perilaku beragama masyarakat Indonesia. Walau Indonesia telah meratifikasi ICCPR, nilai-nilai yang terkandung dalam norma tersebut sering kali tidak 
maksimal. Hal ini dikarenakan hadirnya tekanan domestik (masyarakat) sebagai implementasi sistem demokrasi yang ditetapkan dan standar hukum yang biasanya diterapkan di negara modern yang demokratis, tak terkecuali Indonesia. Sebagai negara demokrasi, produk hukum Indonesia dihasilkan oleh anggota parlemen. Keanggotan tersebut didapatkan melalui suara masyarakat. Keterwakilan mereka sangat dipengaruhi oleh tren politik. Dalam hal ini, keterwakilan anggota parlemen sangat mungkin dipengaruhi oleh suara masyarakat yang diolah dari upaya politik SARA yang dilakukan oleh elit politik (Liputan 6, 2018).

Upaya tekanan dari kaum Islam konservatif sendiri lahir, terutama saat berakhirnya pemerintahan Orde Baru. Berbagai laporan memperlihatkan menguatnya sikap intoleran di kalangan Islam konservatif terhadap individu atau kelompok yang dianggap menyimpang, sehingga eksistensi berbagai kelompok minoritas khususnya dalam Muslim sendiri dipertanyakan (Mudzakkir, 2017: 16). Laporan Wahid Foundation tentang KBB pada tahun 2015 menyatakan bahwa aktor non negara melakukan jumlah pelanggaran KBB sebanyak 89 tindakan. Kelompok massa tercatat melakukan tindakan sebanyak 29 kasus, disusul Majelis Ulama Indonesia (MUI) sebanyak 21 kasus, Front Pembela Islam (FPI) sebanyak 13 kasus dan Simpatisan ISIS sebanyak 3 kasus. Sedangkan pada laporan Outlook KBB tahun 2020 yang dirilis oleh Yayasan Lembaga Bantuan Hukum Indonesia (YLBHI) upaya aktor non negara untuk merepresi tindakan melawan KBB tercermin oleh beberapa kasus seperti kasus Meliana dari Tanjung Balai yang dikriminalisasi karena dianggap menyebarkan kebencian hingga kriminalisasi seorang pegiatKBB diSumatera Barat karena memperjuangkan hak-hak umat kristiani untuk beribadat Natal pada tahun 2019.

Pengaruh dalam penguatan Islam konservatif dapat dilihat dalam berbagaitren maupun gagasan toleransi di Indonesia. Gagasan toleransiyang berkembang dalam gerakan-gerakan di Indonesia cenderung konservatif jika dilihat dari sudut pandang liberalisme. Toleransi yang dinarasikan pada akhirnya lebih mementingkan aspek komunal dibandingkan otoritas individu (Mudzakkir, 2017). Oleh karenaitu, narasi yang tercipta yaitu status quo yang dijaga oleh mayoritas dibandingkan menjamin kebebasan bagi kaum minoritas. Dalam konteks kebebasan agama, sering kali terjadi upaya persekusi, pelarangan rumah ibadah, hingga hambatan untuk melakukan ritual sering dihadapi oleh masyarakat penganut agama minoritas. Oleh karena itu, dapat disimpulkan bahwa desakan masyarakat mayoritas sering kali dijadikan sebagai alasan utama dalam pelarangan tersebut.

Lahirnya berbagai kelompok konservatif Islam pasca Orde Baru menandakan era post-islamisme "yang telah menjadi kecenderungan kultural dan moral di seluruh Indonesia, bahkan sebelum adanya pemerintahan islamis atau partai politik islamis menjadi kekuatan dominan dalam kehidupan bernegara." (Heryanto, 2018: 65). MUI merupakan aktor yang sentral dalam permasalahan penerapan norma KBB. MUI berperan penting dalam menciptakan persepsi forum externum dalam KBB. Fatwa MUI, meski tidak mengikat secara hukum, dianggap otoritatif dan 
diperhatikan baik oleh masyarakat umum maupun pemerintah dalam menyelesaikan isu-isu forum externum dari KBB. MUI menerima kritik pasca fatwa-fatwa yang mereka keluarkan di tahun 2005, yang salah satunya merupakan fatwa mengenai aliran Ahmadiyah sebagai penyimpangan dari ajaran islam.

Sikap MUI akhirnya tidak dapat mencegah kekerasan dan permusuhan terjadi, sebab berbagai pernyataan publik yang dikemukakan pemimpin MUI justru menuntut pemerintah untuk melarang Ahmadiyah ketimbang menekankan untuk dilarangnya tindakan kekerasan terhadap kelompok penganut Ahmadiyah (Bagir, 2018: 161). MUI juga menetapkan fatwa yang menyatakan bahwa pluralisme bertentangan dengan ajaran Islam sebab dalam pandangan MUI, pluralisme menganggap semua agama adalah sama (Bagir, 2018: 162). Yang membuat hal ini berisiko terhadap jaminan KBB adalah pemerintah menganggap MUI sebagai "badan otoritas ulama yang dianggap mewakili Islam normatif" dan pandanganpandangan MUI dijadikan pertimbangan pemerintah dalam praktikpraktik penyelesaian masalah penistaan agama (Bagir, 2018: 162).

Fatwa dan tausiyah MUI tidak mengikat pemerintah dan masyarakat secara hukum. Sebaliknya, pengaruh MUI karena keberhasilannya untuk dalam hal konteks sosial dan politik yang berlaku. Keberhasilan tersebut diraih secara tidak langsung dan berjangka panjang. Seperti contoh, MUI mampu mempengaruhi persepsi masyarakat Islam mengenai suatu peristiwa maupun kebiasaan. Kemandirian MUI yang meningkat juga telah memungkinkannya untuk berpartisipasi aktif dalam perdebatan tentang tempat Islam di masa depan. Warisan ini masih memberikan pengaruh penting pada rancangan undang-undang. Misalnya, MUI berwenang memberikan nasehat tentang hukum nasional yang mungkin berdampak pada umat Islam (Ichwan, 2005: 72).

Implementasi norma KBB di Indonesia dengan demikian sangat dipengaruhi oleh tekanan domestik untuk menafsirkan bagaimana seharusnya masyarakat Indonesia berkeyakinan dan beragama. Berbagai produk hukum yang tidak sesuai dengan norma transnasional KBB tetapi dianggap dianggap negara penting untuk menjaga stabilitas masyarakat itu antara lain: UU Nomor 1/PNPS/1965; PB Menag-Mendagri No.9/8 Tahun 2006 tentang Pembangunan Tempat Ibadah; dan Pasal 2 UU Nomor 1 Tahun 1974 tentang Perkawinan yang mengatur sahnya pelaksanaan perkawinan hanya apabila dilakukan menurut hukum agama masing-masing.

Akan tetapi, upaya negara untuk mengelola permasalahan ini juga tidak dapat dikatakan tepat. Laporan Outlook YLBHI juga memperlihatkan bahwa negara memiliki perspektif yang keliru dalam melihat fanatisme/ kekonservatifan sekelompok masyarakat yang tidak lepas dari identifikasi radikalisme. Salah satunya adalah negara membubarkan Hizbut Tahrir Indonesia (HTI). Upaya ini dilihat sebagai pendekatan yang keliru dalam melihat fenomena radikalisme dan ekstrimisme. Selain itu, negara juga mengambil kebijakan yang reaktif dengan melarang penggunaan cadar dan celana cingkrang kepada ASN. Secara normatif, pelarangan tersebut bertentangan dengan prinsip $\mathrm{KBB}$, karena larangan tersebut akan 
memunculkan stigma dan stereotipe kepada suatu kelompok. Hal tersebut tentu tidak bisa digeneralisasi ke dalam identifikasi paparan radikalisme atau ekstrimisme.

Komnas HAM sebagai aktor lokal di Indonesia berusaha untuk membangun standar norma kebebasan beragama yang ada di Indonesia. Kebutuhan penyusunan standar norma KBB dimaksudkan untuk menjawab kebutuhan pemaknaan, penilaian dan petunjuk atas kaidahkaidah hak asasi manusia dalam peristiwa yang terjadi di masyarakat. Upaya Komnas HAM untuk menyusun standar norma KBB merujuk pada norma transnasional yang diwakili oleh Ratifikasi ICCPR pada UU Nomor 12 Tahun 2005 dan UU Nomor 39 Tahun 1999 dalam sebuah Draft Standar Norma dan Setting Kebebasan Beragama dan Berkeyakinan. Dalam draft tersebut, Komnas HAM berusaha untuk mendefinisikan dan mengakui agama, kewajiban negara, pembatasan, pembahasan toleransi dan kerukunan, pendidikan, penyebaran dakwah, tempat ibadah, identitas simbol, perihal ujaran kebencian, penodaan agama, hak korban, perilaku ASN hingga kewenangan Komnas HAM (Komnas HAM, 2019).

Tujuan utama penyusunan standar tersebut yaitu menjadi tolak ukur untuk menilai atau membandingkan tindakan atau perbuatan yang sejalan dengan HAM maupun yang melanggar HAM. Dalam draft resmi, Komnas HAM menyatakan bahwa dokumen tersebut ditujukan kepada berbagai pihak seperti aparat negara, individu, kelompok masyarakat, korporasi, hingga lembaga pendidikan atau lembaga lainnya. Aparat negara sebagai pelaksana kewajiban diharapkan memastikan terciptanya kebijakan yang tidak diskriminan dan memastikan proses hukum bagi korban maupun pelaku terhadap KBB. Individu sebagai pemegang hak diharapkan memahami segala hal terkait untuk memastikan hak asasinya terlindungi (Komnas HAM, 2019). Kelompok masyarakat diharapkan memahami segala hal terkait sikap toleransi antar umat beragama.

Namun pada perjalanannya, upaya implementasi norma yang dilakukan oleh aktor lokal seperti Komnas HAM mengalami reduksi dalam implementasi UU dan fakta yang terjadi di lapangan, contohnya dalam hal hukum pendirian rumah ibadah. Komnas HAM menyatakan mereka telah menekankan bahwa pembatasan yang berkaitan dengan pendirian dan penggunaan rumah ibadah hanya dapat dilakukan oleh UU, dengan maksud semata-mata untuk menjamin pengakuan serta penghormatan atas hak dan kebebasan orang lain dan untuk memenuhi tuntutan yang adil sesuai dengan pertimbangan moral, nilai-nilai agama, keamanan dan ketertiban umum. Hal ini sejalan dengan Pasal 28H ayat (2) UUD 1945. Pendirian dan penggunaan rumah ibadah juga memperhatikan aspek kesehatan dan keselamatan penggunanya, serta lingkungan sekitarnya. Rumah ibadah harus dimaknai sebagai ruang yang inklusif sebagai sarana membangun hubungan saling menghormati antara sesama pemeluk agama maupun keyakinan dan bersifat netral dari kontroversi isu-isu politik tertentu, serta 
terbebas dari kontroversi ideologi politik tertentu. Korporasi diharapkan menghormati KBB dengan menghindari perlakukan diskriminatif bagi pekerja, dan lembaga pendidikan untuk memberikan kesempatan kepada peserta didik untuk menjalankan ibadah dan keyakinannya (Komnas HAM, 2019).

Meski kebebasan beragama memiliki aspek forum eksternum di mana kebebasan yang salah satunya diwujudkan melalui pendirian rumah ibadah, hal ini sering kali menciptakan ketegangan hingga konflik masyarakat yang berbeda agama. Seringkali, konflik ini mampu berakhir pada tindakan kriminal yang mengatasnamakan kelompok-kelompok masyarakat tertentu. Berbagai contoh kasus konflik pendirian rumah ibadah yaitu GKI Yasmin, HKBP Filadelfia, penolakan renovasi Masjid Al Aqsa di Sentani, Papua hingga penolakan pendirian pura di Desa Sukaurip, Kabupaten Bekasi (The Indonesia Institute, 2015; Wahid Foundation, 2019: Setara Institute, 2018)

Sejatinya, norma transnasional KBB mengamini terdapatnya pembatasan pendirian rumah ibadah yang diatur pada hasil ratifikasi ICCPR melalui UU No. 12 Tahun 2005, khususnya Pasal 18 ayat (3) tentang pembatasan forum eksternum untuk menjaga ketertiban umum. Namun pada implementasi yang dilakukan negara khususnya melalui PB MenagMendagri Nomor 9/Nomor 8 Tahun 2006 malah terjadi sebaliknya. Dalam praktik, produk hukum ini justru menghambat kebebasan beragama dan menciptakan konflik agama. Dalam policy brief yang dikeluarkan The Indonesian Institute, terdapat beberapa kelemahan dalam isi dan implementasi PB di atas (The Indonesia Institute, 2015). Pertama, pemerintah daerah dan pusat dianggap tidak memiliki political will, terutama apabila kepala daerah dihadapkan dengan massa intoleran. Kedua ialah kelemahan sosialisasi kepada masyarakat, terutama oleh Forum Kerukunan Umat Beragama (FKUB). Ketiga ialah lemahnya penegakan hukum. Seringkali, pemerintah daerah gagal untuk menjalankan amanah UU akibat tekanan dari massa intoleran. Terakhir, lemahnya pendidikan multikultural di Indonesia. Pendidikan multikultural sendiri ialah sebuah pendekatan untuk memperbaiki sistem pendidikan yang memunculkan ide-ide mengenai gerakan kesetaraan, keadilan sosial dan demokrasi. Tujuan penting dalam implementasi pendidikan multikultural ialah penekanan atas kelompok budaya yang beragam. Upaya ini berguna untuk menguatkan wawasan masyarakat atas perbedaan ras, etnis, agama, hingga suku untuk tidak menjadi halangan untuk dalam mewujudkan persatuan dan kesatuan.

Merujuk pada pemahaman Acharya mengenai lokalisasi, kegagalan implementasinorma internasional sangat terkait oleh karakteristik kelokalan Indonesia dalam memandang permasalahan KBB. Sejatinya, implementasi

\footnotetext{
${ }^{1}$ Serangan teroris di Filipina, Indonesia dan Malaysia kerap diatributkan kepada al Qaeda yang dikaitkan dengan keberadaan kelompok Abu Sayyaf dan sekutunya di dalam jaringan teroris regional yakni Jemaah Islamiyah, lihat. "a look at major terror attacks in Southeast Asia", http://newsinfo.inquirer.net/139063/a-look-at-major-terrorattacks-in-southeast-asia at 21 October 2015. Dan lihat juga. Peter Chalk, Angel Rabasa and William Rosenau, The evolving terrorist threat to Southeast Asia: A net assessment (Rand Corporation, 2009), 99.
} 
norma KBB sejalan dengan komitmen Indonesia untuk meratifikasi keseluruhan poin dalam ICCPR. Akan tetapi, terjadi perdebatan besar dalam upaya implementasi norma KBB. Dalam konteks nasional, peran aktor konservatif sangat penting, terutama dalam mendefinisikan norma KBB. Doktrin HAM sekuler yang dipahami sering kali dianggap bertentangan dengan prinsip-prinsip dasar masyarakat yang mengakui urgensi agama karena yang pertama didasarkan pada otonomi dan tanggung jawab individu, serta prinsip-prinsip sistemik-rasional, sedangkan yang kedua "didasarkan pada ketundukan individu dan komunitas dengan kehendak Tuhan (Hamid \& Sani, 2011). Sedangkan pada nilai universal HAM yang dikandung dalam norma KBB internasional, tujuan inti HAM sulit untuk dinegosiasikan karena bertujuan untuk menegakkan martabat dan kesetaraan hak seluruh manusia (Donelly, 2013; Grull \& Wilson, 2018).

\section{Kesimpulan}

Jatuhnya rezim otoriter di tahun 1998 menjadi pintu lebar bagi normanorma HAM untuk masuk dan diimplementasikan di Indonesia. Salah satu norma tersebut ialah norma KBB. Indonesia sejatinya telah memberlakukan norma-norma hukum yang menjamin KBB sejak ditetapkannya UUD 1945. Artikulasi norma-norma hukum KBB pun semakin kuat seiring agenda penguatan hukum HAM nasional di awal era Reformasi, yang ditandai dengan ditetapkannya UU Nomor 39 Tahun 1999 dan amandemen kedua UUD 1945 yang memasukkan Bab XA tentang HAM. Kemudian, normanorma hukum positif ini juga terintegrasi secara formil dengan norma hukum internasional tentang jaminan hak atas KBB setelah diratifikasinya ICCPR melalui UU Nomor 12 Tahun 2005. Namun demikian, pemberlakuan norma-norma ini secara nyata belum optimal. Terdapat celah yang cukup besar bagi Indonesia dalam menafsirkan norma KBB Internasional. Selain itu, negara belum memiliki political will yang cukup kuat untuk membangun pemahaman kepada masyarakat Indonesia dan lembaga-lembaga negara secara umum mengenai KBB khususnya jaminan KBB dalam ICCPR. Misalnya, UU Nomor 1/PNPS/1965 tentang Pencegahan Penyalahgunaan dan Penodaan Agama masih berlaku dan sering digunakan sebagai basis dalam perilaku diskriminatif terhadap penganut agama dan kepercayaan minoritas. Selain itu, pandangan MK sendiri terhadap norma-norma KBB juga tidak menunjukkan perhatian terhadap ketentuan hak atas KBB dalam ICCPR.

Kegagalan atau kurang maksimalnya implementasi norma internasional berdampak pada penerapan secara langsung terhadap kekuatan penerapan aturan di ranah masyarakat. Selain itu, ratifikasi yang dilakukan oleh Indonesia tidak menjamin turunan undang-undang terkait mampu menghormati produk norma tersebut. Upaya negara dapat terlihat dari fungsi-fungsi lembaga independen yang mampu mengawal dan menciptakan beberapa poin lanjutan implementasi norma KBB seperti apa yang dilakukan oleh Komnas HAM. Akan tetapi, variabel dalam kesuksesan implementasi norma juga sangat terkait dengan konteks dinamika sosial politik domestik. Hal ini sangat tergantung terhadap bagaimana pemerintah 
menafsirkan konteks sosial dan politik masyarakat. Acap kali, pemerintah terdesak oleh desakan beberapa oknum masyarakat sehingga negara berpotensi menjadi pelanggar atas aturan-aturan KBB yang telah disepakati sebelumnya. Kondisi ini dipengaruhi oleh perang aktor domestik yang berusaha untuk mengkontestasikan narasi universal KBB dengan nilai lokal yang mengakar dan sering kali menjadi panduan bagi kepentingan sosial politik negara. Aktor domestik tersebut salah satunya adalah MUI. Hal ini berdampak pada gagalnya negara untuk melindungi minoritas pemeluk agama tertentu dengan segala hak-hak KBB yang mereka miliki. Kegagalan ini sangat terkait dengan upaya negara yang tidak melokalisasikan norma KBB Internasional. Selain itu, Ketegasan negara dalam implementasi norma HAM internasional adalah faktor penting kesuksesan difusi dan sosialisasi norma HAM pada tataran masyarakat.

\section{Daftar Pustaka}

Asshidiqie, J. (2019) Pengantar Ilmu Hukum Tata Negara, Jilid I. Jakarta: Rajagrafindo Persada.

Acharya, A. (2004). How Ideas Spread: Whose Norms Matter? Norm Localization and Institutional Change in Asian Regionalism. International Organization, 58 (2), pp. 239-275.

Acharya, A. (2009). Whose Ideas Matter? Agency and Power in Asian Regionalism. Ithaca: Cornell University Press.

Citrawan, H. (2014). Menuju ASEAN Political and Security Community: Kritik dan Tantangan Politik Hukum Indonesia dalam Regionalisme ASEAN. Jurnal Rechtsvinding, 3 (2), pp. 237-254.

Donelly J. (2013). The Relative Universality of Human Rights dalam Universal Human Rights in Theory and Practice. Ithaca: Cornell University Press

Finnemore, M \& Sikkink, K. (1998). International Norm Dynamics and Political Change. International Organization, 54 (2) pp. 887-917.

Grüll, C., \& Wilson, E. K. (2018). Universal or Particular ... or Both? The Right to Freedom of Religion or Belief in Cross-Cultural Perspective. Review of Faith and International Affairs, 16 (4), pp. 88-101.

Hamid, D.A. \& Sani. A. (2011). Freedom of Religion in Malaysia: Debates on Norms and Politico-Legal Issues. Human Rights in Southeast Asia Series 1: Breaking the Silence, 647, 75.

Heryanto, A. (2018). Kenikmatan dan Identitas: Politik Budaya Layar Indonesia. Jakarta: Kepustakaan Populer Gramedia

Huelss, H .(2017). After Decision-Making: The Operationalization of Norms in International Relations. International Theory, 9 (3), pp. 381-409.

Ichwan, N. A. (2005). Ulama, State and Politics: Majelis Ulama Indonesia After Suharto. Islamic Law and Society, 12 (1), pp 45-72

Juwana, H. (2006). Human Rights in Indonesia. Indonesian Journal of International Law, 4 (1), pp. 27-60.

Krasner, S. (1983) Internasional Regimes. New York: Cornell University Press.

Komnas HAM Republik Indonesia. (2019) Draf Standar Norma dan Setting Kebebasan Beragama dan Berkeyakinan. Jakarta: Komisi Nasional Hak Asasi Manusia RI. 
Liputan 6. (2018). Isu Sara Terjadi Karena Dimanipulasi Elite Politik [online]. Tersedia di: <https://www.liputan6.com/news/read/3612322/penelitilipi-isu-sara-terjadi-karena-dimanipulasi-elite-politik> (Diakses $25 \mathrm{Mei}$ 2020).

Mahkamah Konstitusi. (2012). Putusan Mahkamah Konstitusi Nomor: 140/ PUU-VII/2012

Mahkamah Konstitusi. (2017). Putusan Mahkamah Konstitusi Nomor: 56/ PUU-XV/2017

March, J \& Olseen, J. (1989) Rediscovering Institutions: The Organizational Basis of Politics. New York: Free Press.

Moeckli, D., Shah, S., \& Sivakumaran, S. eds. (2014) International Human Rights Law. Oxford: Oxford University Press.

Mudzakkir, A. (2017). Konservatisme Islam dan Intoleransi Keagamaan di Tasikmalaya. Jurnal Multikultural dan Multireligius, 16 (1), pp. 57-74.

Risse, T., Ropp, S., \& Sikkink, T. (1999) The Power of Human Rights: International Norms and Domestic Change. Cambridge: Cambridge University Press.

Safa'at, M. (2019). Indonesian Secularities: On the Influence of the StateIslam Relationship on Legal and Political Developments. Working Paper Series of the HCAS "Multiple Secularities - Beyond the West, Beyond Modernities" . Leipzig University.

Setara Institute. (2018). Siaran Pers: Kondisi Kebebasan Beragama/ Berkeyakinan dan Pemajuan Toleransi di Indonesia Tahun 2018 [online]. Tersedia di: <https://setara-institute.org/melawan-intoleransidi-tahun-politik/> (Diakses 21 April 2020).

Smitth, R., \& Asplund, K., eds. (2008). Hukum Hak Asasi Manusia. Yogyakarta: Pusat Studi Hak Asasi Manusia Universitas Islam Indonesia.

Sunstein, C. (1996). Social Norms and Social Roles. Columbia Law Review, 96 (4), 903-968.

Task Force Pemantauan RANHAM (2012). Evaluasi Pelaksanaan RANHAM 2004-2009 dan Rencana Ratifikasi Optional Protocol to the Convention against Torture (CAT) dalam RANHAM 2004-2009 dan Perencanaan RANHAM 2010-2014. Jakarta: The Partnership for Governance Reform.

The Indonesia Institute. (2015). Policy Brief: Evaluasi Peraturan Bersama Menteri Agama dan Menteri Dalam Negeri Nomor 8 dan 9 Tahun 2006 (PBM 2006) Guna Menjaga Kerukunan Umat Beragama.

UN Human Rights Committee. (1993). ICCPR General Comment No. 22: Article 18 (Freedom of Thought, Conscience or Religion), 30 July 1993, CCPR/C/21/Rev.1/Add.4

UN Human Rights Committee, Raihon Hudoyberganova v. Uzbekistan, (2004), U.N. Doc. CCPR/C/82/D/931/2000, para. 6.2 dan UN Human Rights Committee, Sonia Yaker v. France (2016) CCPR/ C/123/D/2747/2016, para.8.7Moec

Viotti, P., \& Kauppi, M. (2012) International Relations Theory. Boston: Longman.

Wahid Foundation. (2018). Mengikis Politik Kebencian: Laporan Tahunan Kemerdekaan Beragama/Berkeyakinan (KBB) di Indonesia 2017. 
Wahid Foundation. (2019). Membatasi Para Pelanggar: Laporan Tahunan Kemerdekaan Beragama dan Berkeyakinan Wahid Foundation Tahun 2018.

Wardaya, S. (2009). Hak Asasi Manusia: Hakekat, Konsep, dan Implikasinya dalam Perspektif Hukum dan Masyarakat. Bandung: Refika Aditama.

Wiratraman, R. (2007). Hak-Hak Konstitusional Warga Negara Setelah Amandemen UUD 1945: Konsep, Pengaturan dan Dinamika Implementasi. Jurnal Hukum Panta Rei, 1 (1), pp. 5-7.

Wiener, A. (2007). The Dual Quality of Norms and Governance beyond the State: Sociological and Normative Approaches to 'Interaction'. Critical Review of International Social and Political Philosophy, 10 (1), pp. 47-69.

Wiener, A. (2014). A Theory of Contestation. New York: Springer.

YLBHI. (2020). Outlook Kebebasan Beragama Atau Berkeyakinan di Indonesia Tahun 2020. Jakarta: Yayasan Lembaga Bantuan Hukum Indonesia.

Yulestiana, A. (2018). Narasi Tentang Advokasi Transnasional dalam SelfDetermination Timor Timur. In: A. Soetjipto (ed.), Transnasionalisme: Peran Aktor Non-Negara dalam Hubungan Internasional (pp. 47-77). Jakarta: Yayasan Obor. 